\title{
The Fatty Acids of Pseudomonas multivorans (Pseudomonas cepacia) and Pseudomonas kingii
}

\author{
By SALLY B. SAMUELS, C. W. MOSS AND R. E. WEAVER \\ Centre for Disease Control, Health Services and Mental Health Administration, Public Health \\ Service, U.S. Department of Health, Education, and Welfare, Atlanta, Georgia, 30333, U.S.A.
}

(Received 5 September 1972; revised 28 September 1972)

\section{SUMMARY}

The fatty acid compositions of three strains of Pseudomonas multivorans and three of $P$. kingii were determined by gas-liquid chromatography. The major fatty acids identified were $16: 0,16: 1,18: 1,3-\mathrm{OH}$ 1 4:0, 3-OH I6:0 and cyclopropane acids I7 $\Delta$ and i9 $\Delta$. The fatty acid compositions of these strains were similar to the acids identified in sixteen clinical isolates of the ' $P$. multivorans $(P$. cepacia)/ $P$. kingii group'. These data support the current view that $P$. multivorans and $P$. kingii are identical species.

\section{INTRODUCTION}

The taxonomic relationship of Pseudomonas cepacia Burkholder (1950) to P. multivorans (Stanier, Palleroni \& Doudoroff, I966) and to P. kingii (Jonsson, 1970) has been the subject of recent studies. Many workers have shown that these species are culturally and biochemically similar (Ballard et al. 1970; Gilardi, 1970; Pickett \& Pederson, 1970; Sands, Schroth \& Hildebrand, 1970). Others have shown that these species are also similar in their genetic composition (Ballard et al. I970; Klein \& Blazevic, I972; Palleroni, Ballard, Ralston \& Doudoroff, 1972).

Chemical analysis of hydrolysates of Pseudomonas species has shown that some of them can be distinguished by differences in fatty acid composition (Moss, Samuels \& Weaver, 1972). One species which is readily differentiated by this procedure is Pseudomonas multivorans ( $P$. cepacia). Since strains of this species cannot be distinguished from $P$. kingii, we have determined if these organisms are similar in fatty acid composition.

\section{METHODS}

Thirteen cultures of the 'Pseudomonas multivorans ( $P$. cepacia)/P. kingii group' were clinical isolates received from various geographical locations by the Centre for Disease Control, Atlanta, Georgia, U.S.A. These cultures, along with the type strains of P. multivorans and $P$. kingii (EO-I), were identified by the Clinical Bacteriology Unit of the Centre for Disease Control according to the procedures outlined in Laboratory Methods in Special Medical Bacteriology (I968). The principal biochemical characteristics of the three type strains of $P$. multivorans (R. Y. Stanier, 382, ATCC I7759; KC984, NCTC I066I ; KC938, ATCC 17460) and of three strains of $P$. kingii (ATCC 25608, ATCC 25609, ATCC 25610) are presented in Table $\mathrm{I}$.

Bacteria for fatty acid analysis were obtained from $24 \mathrm{~h}$ growth $\left(37^{\circ} \mathrm{C}\right)$ in $100 \mathrm{ml}$ of Trypticase Soy Broth* (Baltimore Biological Laboratory, Baltimore, Maryland, U.S.A.)

* Use of trade names is for identification only and does not constitute endorsement by the Public Health Service or by the U.S. Department of Health, Education and Welfare. 
Table I. Principal cultural and biochemical characteristics of three type strains of Pseudomonas multivorans and three ATCC strains of $P$. kingii*

\begin{tabular}{|c|c|c|}
\hline Oxidase & $5 \dagger$ & Number of polar flagella $\geqslant 2$ \\
\hline Acid production, $\mathrm{OF}_{\ddagger}^{+}$(unsealed) & & Motility \\
\hline Glucose & 6 & $\mathrm{H}_{2} \mathrm{~S}$ production \\
\hline Lactose & 6 & Lysine decarboxylase \\
\hline Maltose & 6 & Arginine dihydrolase \\
\hline Cellobiose & 6 & \\
\hline Glycogen & 0 & \\
\hline Erythritol & 0 & \\
\hline Starch & 0 & \\
\hline
\end{tabular}

and on Trypticase Soy Agar (BBL) plates. Washed whole bacteria were saponified with $\mathrm{I} \mathrm{N}-\mathrm{NaOH}$ in $50 \%$ methanol $(\mathrm{w} / \mathrm{v})$ for $\mathrm{I} \mathrm{h}$ at $100{ }^{\circ} \mathrm{C}$. The fatty acids were extracted and methylated by methods described earlier (Moss \& Lewis, 1967).

Fatty acid composition was determined by gas-liquid chromatography (g.l.c.) of methyl esters (Perkin-Elmer Model 900, I $2 \mathrm{ft} \times 0.16$ in column of $3 \%$ OV-I on Chromosorb W, at $150{ }^{\circ} \mathrm{C}$ programmed to $255^{\circ} \mathrm{C}$ at $5{ }^{\circ} \mathrm{C} / \mathrm{min}$, He as carrier gas). Samples were also analysed isothermally at $230^{\circ} \mathrm{C}$ on an $8 \mathrm{ft}$ column of $15 \%$ ethylene glycol adipate (EGA) coated on Chromosorb W with $\mathrm{N}_{2}$ as carrier gas. Eluted compounds were tentatively identified by comparison of retention times on each column with retention times of methyl ester standards. Final identification was established by a combination of techniques including hydrogenation of unsaturated compounds (Brian \& Gardner, 1968), trifluoroacetylation of hydroxy acids (Hancock, Humphreys \& Meadow, 1970), and mass spectrometry (Hancock et al. 1970). Combined g.l.c.-mass spectrometry was carried out on an LKB 9000 instrument. The mass spectra were recorded at $70 \mathrm{eV}$ with an electron energy of $60 \mu \mathrm{A}$, the ion source was at $290^{\circ} \mathrm{C}$, and the molecular separator at $250^{\circ} \mathrm{C}$. The trifluoroacetylated methyl esters were separated on an $\mathrm{I} 8 \mathrm{ft} \times 0.16$ in glass column packed with $3 \% \mathrm{OV}-\mathrm{I}$. Peak areas were determined by direct integration and the percentage of each acid was calculated from the ratio of the area of its peak to the total area of all peaks.

\section{RESULTS}

The range of fatty acids identified in Pseudomonas multivorans ( $P$. cepacia) and $P$. kingii (EO-I) extends from 14:0 to 20:0 (Table 2) and is comparable with that found in several other Pseudomonas species (Moss et al. 1972). Three of the four most abundant acids were palmitic acid (I6:0) and I6:I and I8:I acids. These acids are also major constituents in the lipids of other Pseudomonas species (Romero \& Brenner, 1966; Bobo \& Eagon, 1968; Edmonds \& Cooney, r969; Hancock \& Meadow, I969; Wilkinson, 1969; Kates \& Wassef, 1970; Anderes, Sandine \& Elliker, I97I ; Cullen, Phillips \& Shipley, 197I). More significant was the fourth most abundant acid, 3-hydroxytetradecanoic acid (3-OH 14:0), which has been observed only in $P$. multivorans (Fensom \& Gray, 1969; Hancock et al. 1970; Key, Gray \& Wilkinson, I970; Moss et al. 1972). This hydroxy acid is also present in each culture of $P$. kingii and in each of the thirteen clinical isolates (Table 2) and accounts for approximately 18 to $29 \%$ of the total fatty acids of each strain. Other fatty acids which occurred in each strain were the cyclopropane acids, 9,10-methylene hexadecanoic acid (I7 $\Delta)$ and 


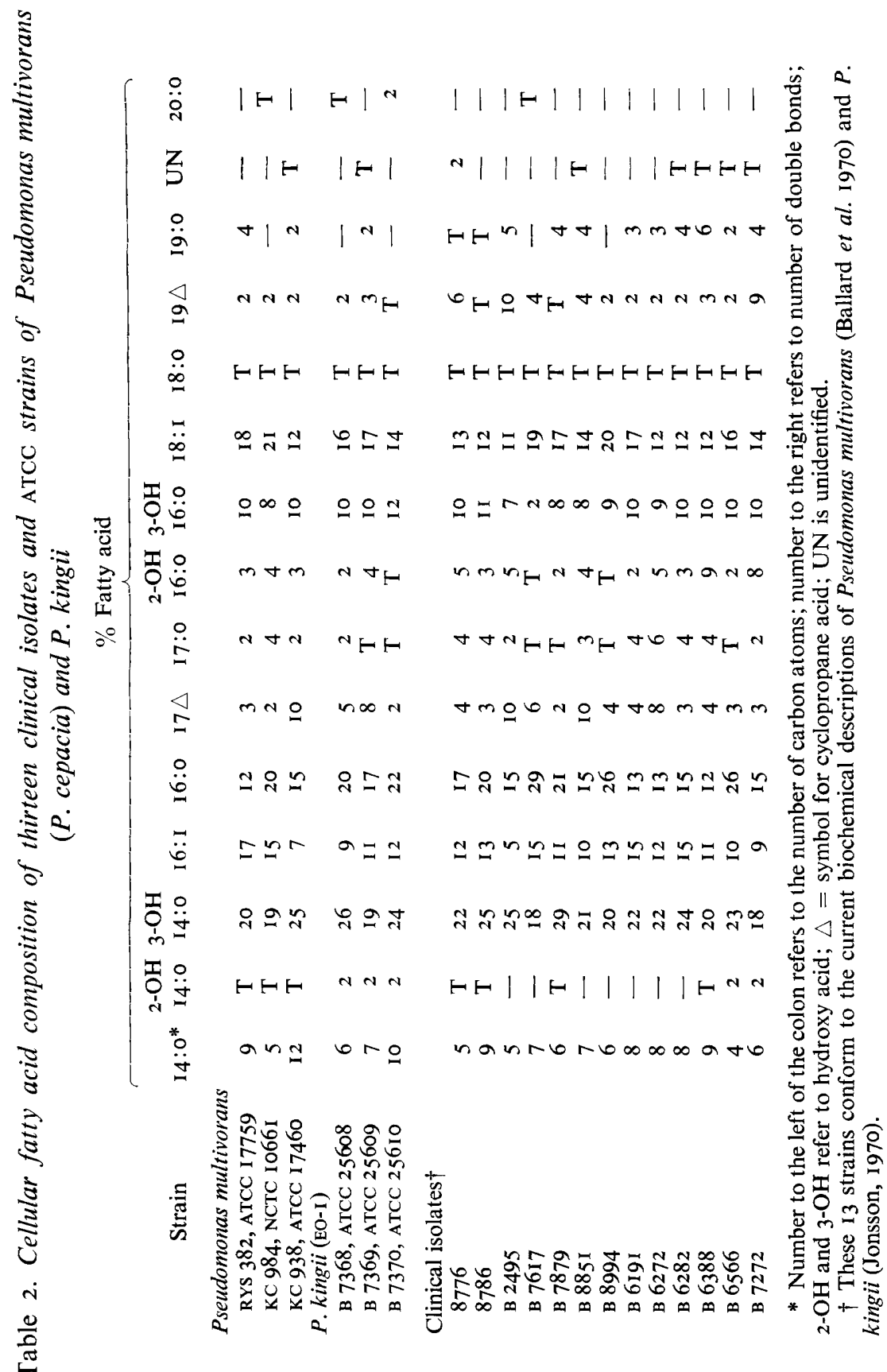


9, I0-methylene octadecanoic acid (I9 $\Delta$ ), which were present in small to trace amounts. Both of these acids have been found in $P$. aeruginosa (Hancock \& Meadow, 1969) and $P$. ftuorescens (Cullen et al. 197I). A second hydroxy acid, 3-hydroxyhexadecanoic acid (3-OH I6:0), was also present in small amounts ( 2 to $12 \%$ ) in each strain. Although the percentage of each fatty acid varied somewhat among strains, the occurrence and relative proportions of these acids in each of the I9 strains produced similar profiles which were different from those of other pseudomonads we have tested (Moss et al. 1972).

All fatty acids were tentatively identified by comparing g.l.c. retention times of their methyl esters with standards on both polar and non-polar columns. Trifluoroacetylated hydroxy acid methyl esters had retention times identical to those of the trifluoroacetylated methyl ester standards of $3-\mathrm{OH} \mathrm{I}_{4}: 0$ and $2-\mathrm{OH} 16: 0$ acids ( $16 \cdot 4$ and $20 \mathrm{~min}$, respectively). As a standard of 3-OH I6:0 acid was not available, tentative identification of this compound was made by g.l.c. retention time data. In extensive studies in our laboratory, we have found that methyl esters of 2-hydroxy acids elute from non-polar columns, such as OV-I, before methyl esters of 3-hydroxy acids of the same chain length. The same elution sequence (2-hydroxy acids before 3-hydroxy acids) is observed for trifluoroacetylated methyl esters on this column. In both instances, the peak tentatively identified as 3-OH I6:0 acid eluted just after the 2-OH $\mathrm{I} 6: 0$ acid standard.

Identification of the methyl esters of normal, cyclopropane, and hydroxy acids was confirmed by mass spectrometry. Each acid gave a fragmentation pattern identical to that of a known standard (Ryhage \& Stenhagen, I960; McCloskey \& Law, I967). Although the 3-OH I6:0 acid could not be compared with a standard, the fragmentation pattern of the methyl ester of this acid was consistent with that of other 3-hydroxy methyl ester standards (i.e. 3-OH I0:0, 3-OH I 2:0, 3-OH I4:0). The mass spectrum showed an m/e I03 peak, an $\mathrm{m} / \mathrm{e} 74$ peak, an M-50 (m/e 236) peak, and an M-I 8 (m/e 268) peak, which are characteristic fragments of 3-hydroxy methyl esters (Ryhage \& Stenhagen, 1963).

\section{DISCUSSION}

The fatty acid compositions of Pseudomonas multivorans ( $P$. cepacia) and $P$. kingii are similar and differ significantly from that of other pseudomonads (Moss et al. 1972). The occurrence of 3-OH $14: 0,3-\mathrm{OH}$ I6:0, and other major fatty acids (Table 2) was consistent throughout a large number of strains from a variety of sources at diverse geographical locations. These data support recent biochemical and genetic studies which have shown that organisms of the ' $P$. multivorans ( $P$. cepacia)/P. kingii group' are identical. Ballard et al. (I970) demonstrated a high level of DNA homology between I 8 strains of $P$. cepacia and the type strain of $P$. multivorans (ATCC I7759); he concluded that the two species are synonymous and that the correct specific designation is Pseudomonas cepacia Burkholder (1950) emend. Other investigators (Gilardi, 1970; Pickett \& Pederson, 1970; Klein \& Blazevic, 1972) have extended the comprehensive biochemical studies of EO-I strains by Jonsson (I970) to show that $P$. kingii (EO-I) is identical to $P$. cepacia and $P$. multivorans. Our fatty acid data also indicate that these are identical species. Therefore, we propose that the original description of Pseudomonas cepacia Burkholder (1950) be amended to include not only $P$. multivorans (Stanier et al. 1966) as suggested by Ballard et al. (1970) but also $P$. kingii (Jonsson, 1970). This would simplify the classification of clinical and phytopathogenic isolates of these species. 
We gratefully acknowledge the assistance of John Liddle for mass spectrometry analysis and Harvey Tatum for the cultural studies.

\section{REFERENCES}

Anderes, E. A., SAndine, W. E. \& Elliker, P. R. (197I). Lipids of antibiotic-sensitive and -resistant strains of Pseudomonas aeruginosa. Canadian Journal of Microbiology I7, I357-1 365.

Ballard, R. W., Palleroni, N. J., Doudoroff, M., Stanier, R. Y. \& Mandel, M. (1970). Taxonomy of the aerobic pseudomonads: Pseudomonas cepacia, P. marginata, P. allucada, and P. caryophylli. Journal of General Microbiology 60, 199-214.

BoBo, R. A. \& EAGON, R. G. (1968). Lipids of cell walls of Pseudomonas aeruginosa and Brucella abortus. Canadian Journal of Microbiology I4, 503-5I 3.

BRIAN, B. L. \& GARDNER, E. W. (I968). A simple procedure for detecting the presence of cyclopropane fatty acids in bacterial lipids. Applied Microbiology 16, 549-552.

BURKHOLDER, W. H. (1950). Sour skin, a bacterial rot of onion bulbs. Phytopathology 40, 1 15-1 17.

Cullen, J., Phillips, M. C. \& Shipley, G. G. (1971). The effects of temperature on the composition and physical properties of the lipids of Pseudomonas fluorescens. Biochemical Journal 125, 733-742.

Edmonds, P. \& Cooney, J. J. (1969). Lipids of Pseudomonas aeruginosa cells grown on hydrocarbons and on trypticase broth. Journal of Bacteriology 98, I6-22.

Fensom, A. H. \& Gray, G. W. (1969). The chemical composition of the lipopolysaccharide of Pseudomonas aeruginosa. Biochemical Journal 114, I85-196.

GILARDI, G. L. (I970). Characterization of EO-I strains (Pseudomonas kingii) isolated from clinical specimens and the hospital environment. Applied Microbiology 20, 52 I-522.

Hancock, I. C., Humphreys, G. O. \& Meadow, P. M. (1970). Characterization of the hydroxy acids of Pseudomonas aeruginosa 8602. Biochimica et biophysica acta 202, 389-39I.

HanCoCK, I. C. \& MEADow, P. M. (I969). The extractable lipids of Pseudomonas aeruginosa. Biochimica et biophysica acta 187, 366-379.

Jonsson, V. (1970). Proposal of a new species Pseudomonas kingii. International Journal of Systematic Bacteriology 20, 255-257.

KATES, M. \& WASSEF, M. K. (1970). Lipid chemistry. Annual Review of Biochemistry 39, 323-358.

Key, B. A., Gray, G. W. \& Wilkinson, S. G. (1970). The purification and chemical composition of the lipopolysaccharide of Pseudomonas alcaligenes. Biochemical Journal I20, 559-566.

Klein, M. M. \& Blazevic, D. J. (1972). Nucleic acid enzyme studies of nonfermentative Gram-negative bacteria using thin-layer chromatography. Applied Microbiology 23, 276-280.

Laboratory Methods in Special Medical Bacteriology (8390-C) (1968). Atlanta, Georgia: Centre for Disease Control.

McCloskey, J. A. \& LAW, J. H. (1967). Ring location in cyclopropane fatty acid esters by a mass spectrometric method. Lipids 2, 225-230.

Moss, C. W. \& LewIS, V. J. (1967). Characterization of clostridia by gas chromatography. I. Differentiation of species by cellular fatty acids. Applied Microbiology r5, 390-397.

Moss, C. W., Samuels, S. B. \& Weaver, R. E. (1972). Cellular fatty acid composition of selected Pseudomonas species. Applied Microbiology (in the Press).

Palleroni, N. J., Ballard, R. W., Ralston, E. \& Doudoroff, M. (1972). Deoxyribonucleic acid homologies among some Pseudomonas species. Journal of Bacteriology x ro, I-I I.

Pickett, M. J. \& Pederson, M. M. (1970). Characterization of saccharolytic nonfermentative bacteria associated with man. Canadian Journal of Microbiology 16, 35I-362.

Romero, E. M. \& BrenNer, R. R. (1966). Fatty acids synthesized from hexadecane by Pseudomonas aeruginosa. Journal of Bacteriology 9I, I83-188.

Ryhage, R. \& Stenhagen, E. (1960). Mass spectrometry in lipid research. Journal of Lipid Research $\mathbf{~}$, $36 \mathrm{I}-390$.

RyHage, R. \& Stenhagen, E. (1963). Mass spectrometry of long-chain esters. In Mass Spectrometry of Organic Ions, pp. 399-452. Edited by F. W. McLafferty. New York: Academic Press.

Sands, D. C., Schroth, M. N. \& Hildebrand, D. C. (1970). Taxonomy of phytopathogenic pseudomonads. Journal of Bacteriology I01, 9-23.

Stanier, R. Y., Palleroni, N. J. \& Doudoroff, M. (1966). The aerobic pseudomonads: A taxonomic study. Journal of General Microbiology 43, 159-27I.

WiLkinson, S. G. (1969). Lipids of Pseudomonas diminuta. Biochimica et biophysica acta 187, 492-500. 